\title{
Présentation du numéro
}

\author{
Clément FRINDEL
}

AVANT-PROPOS

\section{Georges ROZENCWEIG}

Rédacteurs en chef du numéro

L'orthodontiste moderne fait face à un double challenge. Il exerce sa profession en conformité avec les données avérées de la science pour prodiguer à ses patients des soins de qualité, mais il doit également faire face aux obligations légales et administratives qui lui incombent; par exemple gérer les ressources humaines et matérielles du cabinet.

Dans ce cadre, il est en permanence coiffé d'une double casquette :

- celle du praticien qui fait évoluer en permanence sa pratique clinique. Les boîtiers auto-ligaturants, les ancrages vissés, l'orthodontie linguale, les approches orthopédiques et chirurgicales, révolutionnent son exercice ;

- celle du chef d'entreprise qui fait face quotidiennement aux contraintes d'environnement, sociales, administratives, fiscales, et réglementaires.

Ce second volet prend une

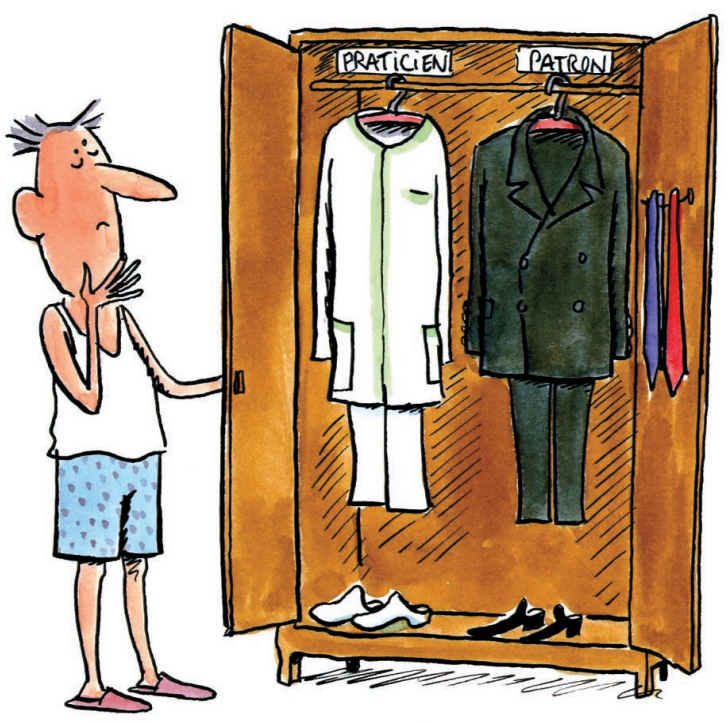
importance de plus en plus grande dans notre vie professionnelle et il a semblé important à l'Association de la Revue d'Orthopédie Dento-Faciale de consacrer un numéro à notre environnement professionnel.

Nous avons choisi d'aborder tous les aspects de la vie du cabinet :

- la conception architecturale de notre cadre de travail,

- les obligations légales et administratives,

- les différents modes d'exercice, 
- la gestion du personnel,

- l'analyse de notre résistance au changement et la conduite de nos projets,

- et la relation patient/praticien.

Dans une grande entreprise, tous ces points clés sont gérés par des équipes performantes, spécialement formées. Dans nos cabinets, l'environnement professionnel est administré par une seule et même personne : le praticien-chef d'entreprise qui met en place des systèmes d'organisation. Ils lui permettent de libérer son esprit, pour soigner ses patients dans une quiétude et une sérénité toutes positives, favorables à la qualité thérapeutique. Dans ce cadre, ses patients sont heureux de venir recevoir leurs soins dans un cabinet bien organisé, bien structuré et où il fait bon respirer la bonne humeur et le plaisir de travailler.

C'est de cet environnement que nous rêvons tous. Gageons que la lecture de ce numéro spécial contribuera à ce que nos rêves deviennent réalité.

Bonne lecture à tous. 


\section{Introduction to this issue}

\section{Clément FRINDEL}

\section{Georges ROZENCWEIG}

Editors in chief of this issue

Modern orthodontists have to face a double challenge: not only must they practice their profession in accordance with the most up-to-date scientific concepts and data bases in order to provide their patients with superb treatment but they must also deal with the legal and administrative obligations of directing a business enterprise, primarily managing the human and material resources of their offices.

They must wear two hats, neither of which can ever be removed.

- The first is that of practicing orthodontists who are also permanent students, enrolled in continuously renewed courses of continuing education that keep them abreast of the latest developments, which include self-ligating brackets, mini-screw temporary anchorage, lingual orthodontics, and orthopedic and surgical treatment, all of which have revolutionary implications for practice.

- The second is that of Chief

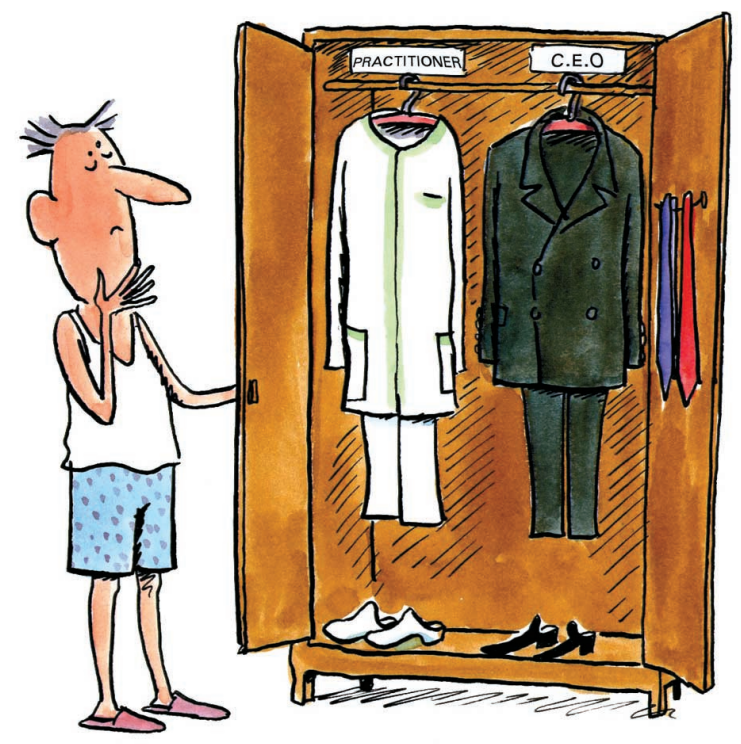
Executive Officers who must deal every day with the environmental, social, administrative, fiscal, and regulatory constraints of running a business.

Because the second category is becoming an increasingly crucial component of our daily professional lives the Association of the Revue d'Orthopédie DentoFaciale has decided to devote this issue of the journal to our professional environment.

We have determined to examine the conduct of our practices from every aspect:

- the architectural conception of the structures in which we work,

- our legal and administrative obligations, 
- the different modes of practice,

- the management of personnel,

- an analysis of our resistance to change and a review of the way projects can be conducted,

- he doctor/patient relationship.

In a large enterprise, permanent specially trained teams deal with the key elements of the undertaking. In our offices, which are more limited in scope, a single person, the practitioner/CEO, administers the whole range of professional activity, setting up all the organizational systems. These are designed to protect the practitioners' tranquility so that they can treat patients in a quiet, serene, and positive atmosphere that nourishes therapeutic excellence. In this setting, patients are happy when they arrive for their office visits knowing that they will receive treatment in a well organized and well structured office where doctors and staff work in an aura of good humor as they delight in delivering first class care.

This is the environment of our dreams. We are sure that a careful inspection of this special issue will help our readers make these dreams become a reality.

We hope you all like it and benefit greatly from reading it. 